sióstr w nauczaniu wiernych. Ks. Prof. Karol Mrowiec CIM wygłosił referat pt. Wychowawcza rola choratu gregoriańskiego $w$ życiu młodzieży zakonnej, omawiając wartości estetyczne, ascetyczne i mistyczne chorału, Po południu O. Szczaniecki OSB przeprowadził lekcję recytacji i śpiewu oficjum dla przedstawicielek zakonów klauzurowych. Ks. Prof. Jankowski odprawił Nieszpory o NMP, po czym J. E. Ks. Bp Antoni Pawłowski wygłosił kazanie końcowe, a J. E. Ks. Bp Czajka udzielił uczestnikom błogosławieństwa N. Sakramentem.

Dni chorału gregoriańskiego wykazały, że wiele sióstr przyswoiło już sobie poprawną technikę śpiewu gregoriańskiego, a niektóre z nich potrafią go nauczać. Są to poważne osiągnięcia, jeżeli weźmie się pođ uwagę kataklizmy, które przeżyły polskie zgromadzenia w związku z dwiema wojnami światowymi. Strona organizacyjna zjazdu spoczywała na barkach Księży Profesorów: Jankowskiego i Lewkowicza, którym można gratulować owoców pracy nad szkoleniem sióstr w śpiewie gregoriańskim.

Tyniec

O. FRANCISZEK MALACZYŃSKI OSB

\title{
TRZECIE SEMINARIUM BIBLIJNE
}

W dniach od 5 do 7 września br. odbyło się w Gnieźnie trzecie z kolei naukowe seminarium biblistów polskich. Wzięło w nim udzial 67 profesorów Pisma św. zarówno z diecezjalnych seminariów duchownych jak i z zakonnycb zakładów teologicznych. Uczestnicy seminarium wychodząe z założenia, że Biblia to nie tylko zwykła księga, która kształci nasz umysł i wzbogaca naszą wiedzę, ale to także księga boża, która formuje życie wewnętrzne człowieka, nadali swoim obradom dwa nurty: Jeden ascetyczno-wewnętrzny, oparty o nabożeństwa, konferencje religijne i modlitwę, a drugi teologiczno-naukowy, bazujący na referatach, dyskusji i wnioskach, dotyczących pracy biblijnej w przyszłości.

Obrady rozpoczynano codziennie IMszą św., połączoną z okolicznościowym przemówieniem. W pierwszym dniu odprawił ją w kaplicy Arcybiskupiego Seminarium Duchownego gospodarz seminaruim naukowego, Ks, prof. Fel. Kłoniecki, który także przemówił na temat wartości i znaczenia Pisma św. W życiu kapłana. W drugim dniu Mszę św. celebrował w zastępstwie nieobecnego Ks. Prymasa, JE. Ks. Bp Lucian Bernacki. W swoim głębokim i podniosłym przemówieniu wskazał Dostojny Celebrans, że studia biblijne to najtrudniejsze ale i najważniejsze studia, na których opierają się i z których czerpią argumenty dla siebie wszystkie niemal dyscypliny teologiczne, szczególnie dogmatyka moralna, apologetyka itp. Opatrzność Boża jakby na dzisiejsze czasy mówił dalej Ks. Biskup - zachowała nam i dostarczyła szeregu dowo- 
dów potwierdzających prawdziwość Pisma św., w formie odkrytych w Egipcie papirusów, w Qumran szeregu zwojów z manuskryptami biblijnymi oraz przez stale prowadzone wykopaliska, $z$ których jak dotąd żadne nie zakwestionowało historyczności biblijnych opowiadań. Pod koniec swego przemówienia JE. Ks Biskup zwrócił się do zebranych profesorów, by zechcieli jak najszybciej dostarczyć szerokim rzeszom kapłanów podręcznik Teologii Biblijnej, w której duszpasterze mogliby znaleźć ułożoną w sposób naukowy a zarazem przystępny całą prawdę bożą zawartą w Piśmie św.

W trzecim dniu obrad Ks. prof. Wł. Smereka z Krakowa odprawil Mszę św. za zmarłego niedawno nestora biblistów polskich śp. ks. prof. Piotra Stacha oraz za innych biblistów, którzy zginęli w czasie ostatniej wojny. Codziennie wieczorem o godz. 20 po krótkim nabożeństwie O. Ludwik Nowak Generał OO. Paulinów wygłaszał podniosłe konferencje religijne, oparte o egzegezę przypowieści ewangelicznych oraz listów pawłowych.

Tematyka wygłaszanych referatów i dyskusji obracała się wokoło zagadnienia „Chrystocentryzm w Piśmie świętym”. W pierwszym dniu wygłoszono następujące referaty: O. IM. Stolarczyk, CP., „Harmonia Starego $i$ Nowego Testamentu", którego koreferentem był Ks. J. Ku dasiewicz z Kielc. Referent ujął zagadnienie z punktu widzenia teologicznego, zaś koreferent uwzględnił aspekt filologiczno-literacki tego zagadnienia. Z kolei wygłoszono referaty: Ks. Z. Ka znowski z Krakowa pt. „Geneza starotestamentowej biografii Chrystusa” (Koreferat Ks. J. Łach z Tarnowa), Ks. M. W oln iew ic z z Poznania „Chrystologia św. Pawła we wspótczesnej egzegezie”, O. H. Langhamer OFM. „Apokryfy o Męce i Zmartwychwstaniu Chrystusa Pana" (Koreferat Ks. P. Szefler z Płocka).

Dzień drugi seminarium rozpoczął się referatem Ks. St. P o tockieg o z Przemyśla na temat: „Aspekty teologiczne prawa mojżeszowego”, którego koreferentem był Kis. St. Grzybek z Krakowa. W dyskusji jaka rozwinęła się po obu referatach zabierali głos między innymi JE. Ks. Bp Bernacki z Gniezna, Ks. St. Ea ch z Lublina i Ks. M. P e ter z Poznania. Wszyscy stwierdzili jednozgodnie, że prawo mojżeszowe miało przede wszystkim religijny charakter oparty o Przymierze jakie zawarł Bóg-Jahwe $\mathrm{z}$ narodem wybranym.

Następne referaty $w$ tym dniu wygłosili O. E. Haratym TJ., pt. „Daniel widzqcy” oraz O. F. Bogacewicz OFMC. pt. „Charakter Chrystusa wedtug czterech Ewangelii".

Trzeci dzién dostarczył referatów opartych o najnowsze badania i zdobycze naukowe dotyczące osoby samego Chrystusa. Wygłosili je: Ks. A. Jańczak SCJ pt. „Problem historyczności Chrystusa we wspótczesnej literaturze biblijnej" (Koreferat O. J. R o słon OFMC) oraz Ks. L. Stefaniak CIM., pt. „Poglady mesjańskie czy eschatologiczne sekty 
$z$ Qumran" (Koreferat Ks. J. Jóź w i a k z Włocławka). Wszystkie referaty jak również rzeczową i twórczą dyskusję cechowal wysoki poziom i wszechstronne przygotowanie się nie tylko samych referentów ale i wszystkich uczestników seminarium naukowego.

Osobną może najbardziej interesującą częścią tego seminarium naukowego było sprawozdanie $\mathrm{z}$ wydawnictw biblijnych złożone przez odpowiednich przedstawicieli poszczególnych ośrodków naukowych. O. A. J a nkowski z Tyńca zreferowal stan prac związanych $\mathrm{z}$ wydaniem tzw. Biblii Tynieckiej, która będzie pierwszym polskim tłumaczeniem Pisma św. z języków oryginalnych wydanych w całości w jednym tomie. Biblia ta ukaże się w przyszłym roku. Ks. St. Ła ch Dziekan K. U.L.-u mówił o redagowanym przez siebie Komentarzu Tysiąclecia do St. Testamentu, którego I tom już wyszedł z druku (Ks. Machabejskie), w roku następnym ukażą się dalsze tomy (Księgi Tobiasza, Judyty i Estery). W druku jest także Historia Biblijna Starego Testamentu, pióra Ks. J. Jelity $\mathrm{z}$ Katowic. Ks. Wł. S mereka mówił o wydawanym przez P.T.T. „Ruchu Biblijnym i Liturgicznym”, który jest jedynym czasopismem, poruszającym u nas problematykę ściśle biblijną.

$\mathrm{Na}$ zakończenie należy podkreślić, że naukowe seminarium biblijne zorganizowała Sekcja Biblijna K.U.L. z JE. Ks. Bpem H. Strąkowskim, Ks. St. Łachem i Ks. F. Gryglew iczem na czele, którym za trud organizacji, przeprowadzenie i wykonanie zamierzone planu należy się serdeczne podziękowanie.

Kraków

Ks. STANISŁAW GRZYBEK 